\title{
Managing of Early Blight of Tomato Caused by Alternaria solani through Fungicides and Bioagents
}

\author{
Raavi Sreenivasulu ${ }^{1 *}$, M. Surya Prakash Reddy², D. S. Tomar', \\ M. Subhash Sri Sanjay ${ }^{2}$ and Bharath Bushan Reddy ${ }^{2}$
}

${ }^{1}$ Department of Plant Pathology College of Agriculture, JNKVV, Tikamgarh, India

${ }^{2}$ Department of Plant Pathology, College of Agriculture, JNKVV, Jabalpur, India

*Corresponding author:

\begin{abstract}
A B S T R A C T
Alternaria leaf blight of tomato caused by Alternaria solani is a soil inhabiting and airborne pathogen responsible for considerable loss in tomato production. In the absence of resistant cultivars, the use of fungicides and biocontrol agents to control the disease is one

Keywords

Tomato, Alternaria solani, Fungicides, Bioagents

Article Info

Accepted:

12 May 2019

Available Online:

10 June 2019 exercise training. When there is an epidemic outbreak for some reason, perhaps the use of fungicides are one of the best options available. These fungicides must be used judiciously according to the need, type of body involved and availability of new fungicides. It requires the evaluation of fungicides under in vivo and in vitro conditions to know its effectiveness, start the spray schedule in field conditions and for developing a cost effective disease management approach. The present investigation based of five fungicides and two bioagents against Alternaria solani under in vivo and in vitro conditions. These fungicides show significant effect inhibitions to the pathogen in vitro and in vivo conditions. The Tebuconazole $25.9 \%$ EC @ 0.1\% was most effective followed by propiconazole 25\%EC @ $0.1 \%$ and copper oxychloride $50 \%$ WP @ $0.30 \%$ less in found fairly economical for the management of early blight disease along with significantly highest fruit yield. The biocontrol agents, foliar spraying of fungal bioagents i.e. Trichoderma viride @ 0.25\% was proved highly effective followed by bacterial bioagent i.e. Pseudomonas fluorescens @ $0.25 \%$.
\end{abstract}

\section{Introduction}

Tomato (Solanum lycopersicum Linnaeus), native to the Andean region of South America, is one of the most common horticultural crops and cultivated throughout the world. It can be grown in a wide range of climates from tropical to temperate. Tomato early blight disease caused by Alternaria solani become the most destructive in all over the world and yield losses up to $80 \%$ (Chandravanshi et al., 1994). The disease in severe cases can lead to complete defoliation and is most damaging on tomato in regions with heavy dew, rainfall, high humidity, and fairly high temperatures. All above ground parts of the plant can have symptoms of this disease. Tomato crop is vulnerable to infect by bacterial, viral, nematode and fungal diseases. Among the fungal diseases, 
Alternaria leaf blight of tomato caused by Alternaria solani (Ellis and Martin) Jones and Grout, is a soil inhabiting air-borne pathogen responsible for leaf blight, collar and fruit rot of tomato disseminated by fungal spores (Datar and Mayee, 1981). Alternaria solani contains enzymes such as cellulases which degrade the host cell wall and also contain pectin methyl galacturonase which facilitate host colonization (Shahbazi et al., 2011). Disease affect crop production as they cause premature defoliation and result in heavy losses in production by reducing quality and quantity of fruit (Holm et al., 2003). Crowded plantation, high rainfall and extended period of leaf wetness are responsible factors to induce disease development (Gondal et al., 2012). This disease is very difficult to control (Pasche et al., 2004). Failure to control this disease can cause reduction in yield (Malik et al., 2014). It need to develop new effective fungicide and bioagents with mode of action which will be helpful for increase in quality and quantity of tomato production (Sahu et al., 2013). However, the present work was designed to investigate the efficacy of five Fungicides and two bioagents against the menace of early blight pathogen under laboratory and field conditions.

\section{Materials and Methods}

The field experiments were carried out in the research field under department of Plant Pathology, while the lab works were conducted in the laboratories under departments of Plant Pathology JNKVV, College of Agriculture Tikamgarh (MP) during 2018-19.

\section{Seeds}

Seeds of tomato variety KashiAnupam were procured from Indian Institute of Vegetable Research (IIVR) Varanasi (UP).

\section{Fungicides}

Fungicides were used for the experiments and are presented in the table separately.

Radial growth in control (C) -

Radial growth in the treatment $(\mathrm{T})$

Inhibition $=$

Radial growth in control(C)

Isolation of pathogen from diseased
samples

The leaves, stems and fruits of diseased plant showing typical symptoms were washed thoroughly with tap water; small pieces of infected leaves were cut with the help of sterilized blade. These pieces were surface sterilized with 1:1000 mercuric chloride $\left(\mathrm{HgCl}_{2}\right)$ solution for one minute followed by three washings with sterilized distilled water to remove traces of $\mathrm{HgCl}_{2}$.

The pieces were then transferred aseptically to Petri plates containing Potato dextrose agar medium. Inoculated Petri plates were incubated at $25 \pm 2{ }^{\circ} \mathrm{c}$ for three to five days and examined at frequent intervals to see the growth of the fungus developing from different pieces. As and when fungal colony appeared they were transferred to PDA slant.

In vitro evaluation of chemical fungicides and bioagents against Alternaria solani

The efficacy of five fungicides viz., Tebuconazole $(0.10 \%)$, Propiconazole $(0.10 \%)$, Carbendizim + Mancozeb $(0.15 \%)$, Mancozeb $(0.25 \%)$ and Copper oxychloride (0.30\%) Trichodermavirideand Pseudomonas fluorescens were tested against $A$. solani on Potato dextrose agar medium using poisoned food technique (Nene and Thapliyal, 1979) and dual culture technique (Morton 1955) using PDA as basal medium under in vitro condition. 
In vivo evaluation of fungicides and bio agents against Alternaraia solani

The experiment was conducted at, JNKVV College of Agriculture, Tikamgarh (MP). During the year 2018-19 in Rabi season using cv. KashiAnupam to test the efficacy of fungicides and bioagents. Thirty to thirty five days old seedlings raised in nursery were transplanted in the month of October at a distance of $60 \mathrm{~cm} \mathrm{X} 45 \mathrm{~cm}$ spacing with the gross area of $39.5 \mathrm{~m} \mathrm{X} 11 \mathrm{~m}=434.5 \mathrm{~m}^{2}$. Efficacies of five fungicides and two bio control agents with their prefixed concentrations (as per treatments) were compared with untreated control. Two sprays of each fungicide and biocontrol agents with their prefixed concentration were applied at an interval of 15 days after the initiation of the disease. The per cent disease intensity was recorded for each plot and compared with control plot after two consecutive sprays of fungicides and bio control agents at 15 days intervals. On the basis of symptoms and microscopic studies, the fungus was identified as Alternaria solani, causative agent of early blight of tomato (Ellis and Martin, 1882) Jones and Grout, 1897. The observations on the intensity of early blight disease of tomato were recorded from 5 randomly selected plants from each plot using 0-5 scale.

\section{Procedure for recording disease intensity}

Five randomly selected plants from each plot and three leaves (Top, Middle and Bottom) from each plant were examined for the Alternaria solani symptoms and also examined microscopically for the disease. Based on number of infected plants from each field, per cent disease intensity of early blight was calculated for each plot.

Percent Disease Intensity (PDI) was calculated by using the following formula given by (Pandey et al., 2002).

\author{
Sum of all disease ratings \\ PDI = ------------------------------- x 100 \\ Total no. of observations (sample) $\mathrm{X}$ \\ Maximal disease rating grade
}

\section{Fruit yield data}

In the field experiments (Rabi, 2018-19) well mature and ripen tomato fruits were harvested regularly in all the replicated treatments. The fruit yield per plot was recorded and extrapolated to give the value of fruit yield in quintal ha ${ }^{-1}$.

\section{Results and Discussion}

The efficacy of five fungicides and two bioagents against $A$. solani at prescribed doses which are earlier described in methods and materials were evaluated (Table 1). The data presented in Table 1 and Figure 1 revealed that all the tested fungicides and bioagents significantly inhibited radial growth of the test pathogen over untreated control (Plate. A). All the fungicides evaluated caused inhibition of mycelial growth of pathogen. Among the chemical fungicides Tebuconazole $25.9 \quad \% \quad$ EC @ $0.1 \%$, Propiconazole 25\%EC @ $0.1 \%$ and Mancozeb 75 \%WP @ $0.25 \%$ were significantly superior over Copper Oxy chloride 50 WP @ 0.30\%, in inhibiting mycelial growth. The 100 per cent inhibition was observed in treatment Tebuconazole 25.9 $\%$ EC @ $0.1 \%$ and it was followed by treatment Propiconazole 25\%EC @ $0.1 \%$ (90.26\%), Mancozeb $75 \% \mathrm{WP} @ 0.25 \%$ $(87.57 \%)$ and Carbendazim $12 \%+$ Mancozeb $63 \%$ WP @ $0.15 \%$ (80.81\%). While minimum inhibition was observed in treatment Copper Oxy chloride 50 WP @ $0.30 \%(40.54 \%)$. Among the biocontrol agents Trichoderma viride (47.29\%) was superiorto Pseudomonas fluorescens (18.91\%). Herle and Kamanna (2014) evaluated twelve fungicides viz., 
Hexaconazole, Tebuconazole, Propiconazole, combination products Zineb 68\% + Hexaconazole $4 \%$ and Captan $70 \%+$ Hexaconazole $5 \%$ under in vitro conditions against Alternaria solani. Similar observation
Vijayalakshmi et al., (2018) reported maximum inhibition of radial growth of $A$. helianthi was observed in T. viride $(85.33 \%)$ which was followed by $T$. viride strain 16 (79.33\%), and T. harzianum (76.44\%).

List of fungicides and bioagents used in experiment

\begin{tabular}{|c|c|c|c|}
\hline S. No. & Common Name & Trade Name & Dose (\%) \\
\hline 1 & Tebuconazole 25.9\% EC & Cark & 0.1 \\
\hline 2 & Propiconazole 25\%EC & Kontrol & 0.1 \\
\hline 3 & Carbendazim 12\% + Mancozeb 63\% WP & Saaf & 0.15 \\
\hline 4 & Mancozeb 75\%WP & Dhanuka M-45 & 0.25 \\
\hline 5 & Copper Oxychloride 50 \% WP & Maincop & 0.30 \\
\hline 6 & Pseudomonas fluorescens (Liquid \\
formulation) & $\begin{array}{c}\text { Procured from JNKVV, } \\
\text { Microbiology department }\end{array}$ & 0.25 \\
\hline 7 & Trichoderma viride (Liquid formulation) & $\begin{array}{c}\text { Procured from JNKVV, } \\
\text { Microbiology department }\end{array}$ & 0.25 \\
\hline
\end{tabular}

\section{Disease description scale}

\begin{tabular}{|c|c|}
\hline Scale & Description \\
\hline $\mathbf{0}$ & No symptoms on the leaf \\
\hline 1 & $0-5$ percent leaf area infected and covered by spot \\
\hline 2 & 6-20 percent leaf area infected and covered by spot, some spots on petiole \\
\hline 3 & $\begin{array}{l}21-40 \text { percent leaf area infected and covered by spot, spots also seen on } \\
\text { petiole, branches }\end{array}$ \\
\hline 4 & $\begin{array}{l}\text { 41-70 percent leaf area infected and covered by spot, spots also seen on } \\
\text { petiole, braches, stem }\end{array}$ \\
\hline 5 & $\begin{array}{l}>71 \text { percent leaf area infected and covered by spot, spots also seen on petiole, } \\
\text { branch, stem, fruits }\end{array}$ \\
\hline
\end{tabular}

\section{Treatments}

\begin{tabular}{|c|c|c|}
\hline Treatment No. & Treatment details & Dose (\%) \\
\hline $\mathbf{T}_{\mathbf{1}}$ & Tebuconazole 25.9\% EC & 0.1 \\
\hline $\mathbf{T}_{\mathbf{2}}$ & Propiconazole 25\%EC & 0.1 \\
\hline $\mathbf{T}_{\mathbf{3}}$ & Carbendazim 12\% + Mancozeb 63\% WP & 0.15 \\
\hline $\mathbf{T}_{\mathbf{4}}$ & Mancozeb 75\%WP & 0.25 \\
\hline $\mathbf{T}_{\mathbf{5}}$ & Copper oxychloride 50\% WP & 0.30 \\
\hline $\mathbf{T}_{\mathbf{6}}$ & Pseudomonas fluorescens & 0.25 \\
\hline $\mathbf{T}_{\mathbf{7}}$ & Trichoderma viridae & 0.25 \\
\hline $\mathbf{T}_{\mathbf{8}}$ & Control & - \\
\hline
\end{tabular}


Table.1 Evaluation of fungicides and bio agents against $A$. solani by food poison technique and dual culture technique after 7 days of inoculation (In vitro)

\begin{tabular}{|c|c|c|c|}
\hline Fungicides and bioagents & Dose $(\%)$ & Radial growth (mm) & Per cent inhibition (\%) \\
\hline \multicolumn{4}{|l|}{ Food poison technique (Fungicides) } \\
\hline Propiconazole $25 \% \mathrm{EC}$ & 0.1 & 6 & 90.26 \\
\hline Mancozeb $75 \% \mathrm{WP}$ & 0.25 & 7.66 & 87.57 \\
\hline Copper Oxychloride $50 \%$ WP & 0.30 & 36.66 & 40.54 \\
\hline \multicolumn{4}{|l|}{ Dual Culture (bioagents) } \\
\hline Trichodermaviride & - & 32.5 & 47.29 \\
\hline Control & - & 61.66 & - \\
\hline SEm+ & & 1.12 & \\
\hline CD at $5 \%$ & & 3.41 & \\
\hline $\mathbf{C V}$ & & 7.58 & \\
\hline
\end{tabular}


Table.2 Evaluation of fungicides and bio agents against Alternaria solani (In vivo)

\begin{tabular}{|c|c|c|c|c|c|c|}
\hline SI. NO & Treatments & Dose (\%) & PDI & PDC & Yield q/ha & $\begin{array}{c}\% \text { Increase in yield } \\
\text { over control }\end{array}$ \\
\hline 1 & Tebuconazole $25.9 \%$ EC & 0.1 & $\begin{array}{c}14.22 * \\
(22.15)^{* *}\end{array}$ & 73.50 & 216.20 & 100.37 \\
\hline 2 & Propiconazole $25 \% \mathrm{EC}$ & 0.1 & $\begin{array}{c}17.55 * \\
(24.64)^{* *}\end{array}$ & 67.30 & 213.97 & 98.30 \\
\hline 3 & Carbendazim 12\% + Mancozeb $63 \%$ WP & 0.15 & $\begin{array}{l}22.21 * \\
(28.10)\end{array}$ & 58.62 & 164.63 & 52.57 \\
\hline 4 & Mancozeb $75 \%$ WP & 0.25 & $\begin{array}{c}19.99 * \\
(26.45)^{* *}\end{array}$ & 62.76 & 178.20 & 65.15 \\
\hline 5 & Copper oxychloride $50 \%$ WP & 0.30 & $\begin{array}{c}26.66 * \\
(31.08)^{* *}\end{array}$ & 50.33 & 162.17 & 50.29 \\
\hline 6 & Pseudomonas fluorescens & 0.25 & $\begin{array}{c}34.88 * \\
(36.19) * *\end{array}$ & 35.02 & 128.13 & 18.74 \\
\hline 7 & Trichodermaviride & 0.25 & $\begin{array}{c}19.55^{*} \\
(26.11)^{* *}\end{array}$ & 63.58 & 179.93 & 66.75 \\
\hline 8 & Control & - & $\begin{array}{c}53.68 * \\
(47.17)^{* *}\end{array}$ & - & 107.90 & - \\
\hline 9 & SEm \pm & & $\begin{array}{c}\text { 3.06* } \\
(1.97)^{* *}\end{array}$ & & 13.43 & \\
\hline 10 & CD at $5 \%$ & & $\begin{array}{c}9.38 * \\
(5.73)^{* *}\end{array}$ & & 39.09 & \\
\hline 11 & $\mathbf{C V}$ & & $\begin{array}{c}20.34 * \\
(11.28)^{* *}\end{array}$ & & 13.78 & \\
\hline
\end{tabular}

* Mean of three replications

** Figure in parenthesis are transformed (angular) values 
Fig.1 In vitro evaluation of fungicides and bio agents against $A$. solani by food poison technique and dual culture

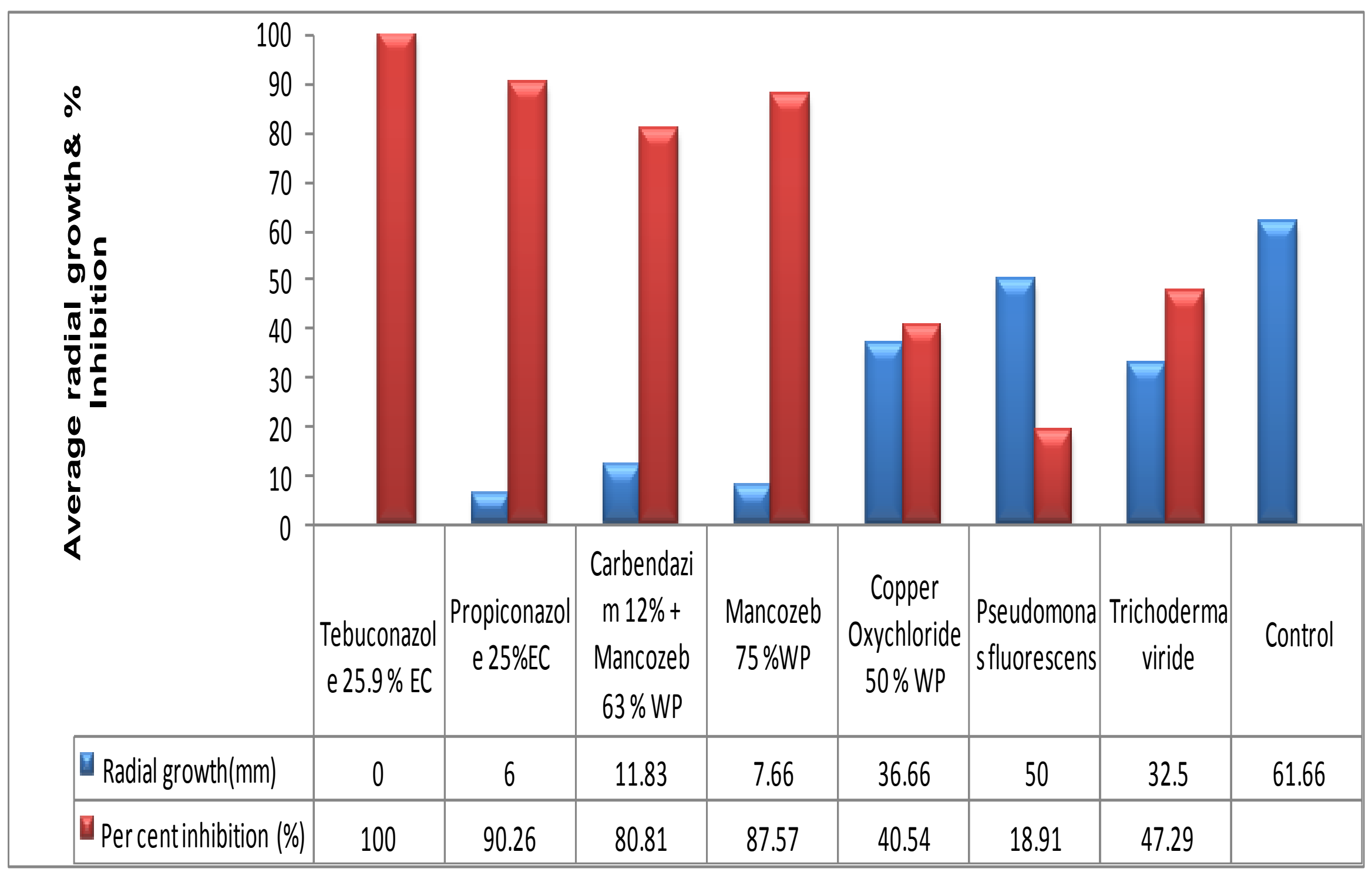


Fig.2 In vivo evaluation of fungicides and bio agents against Alternaria solani

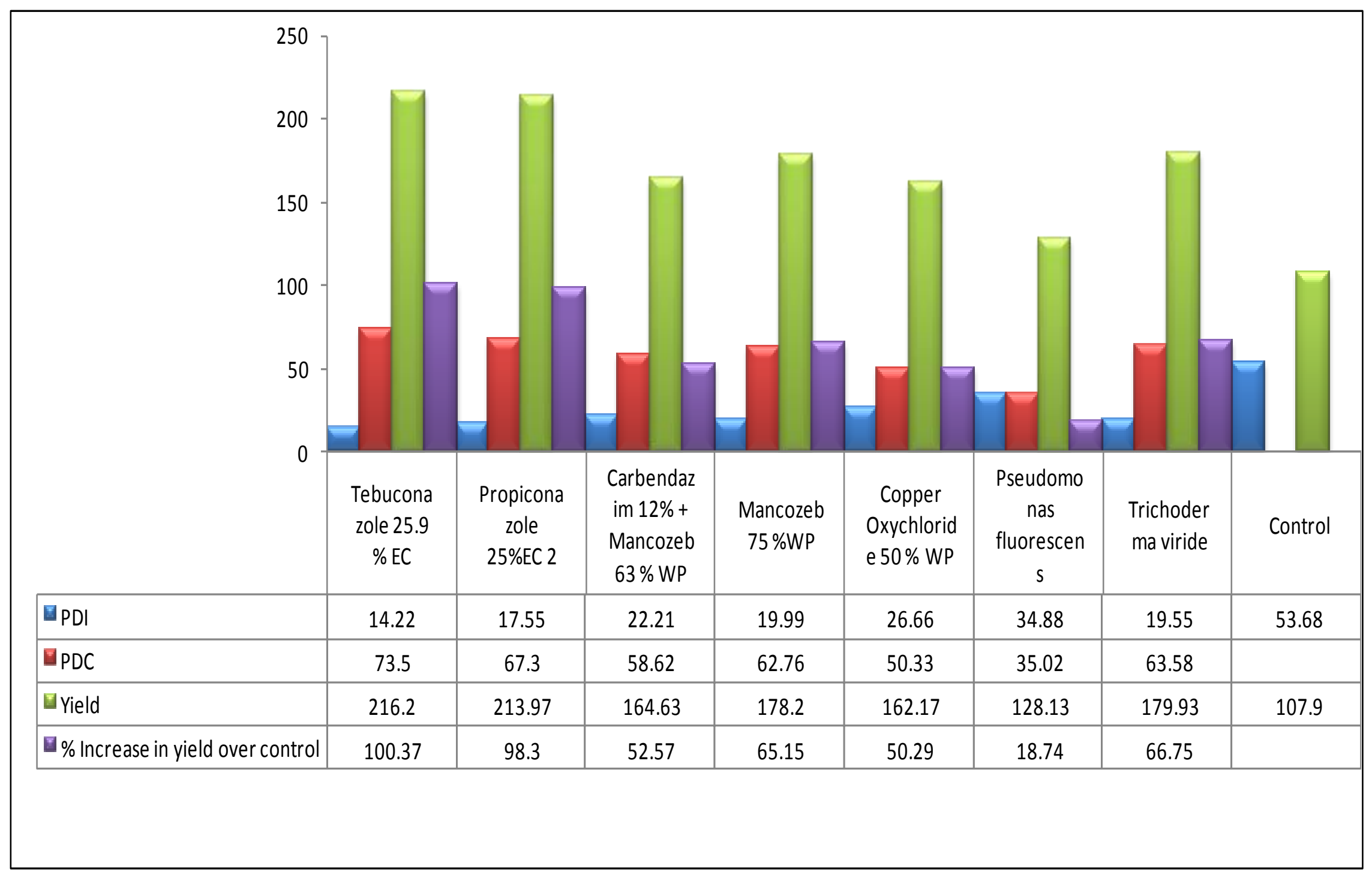




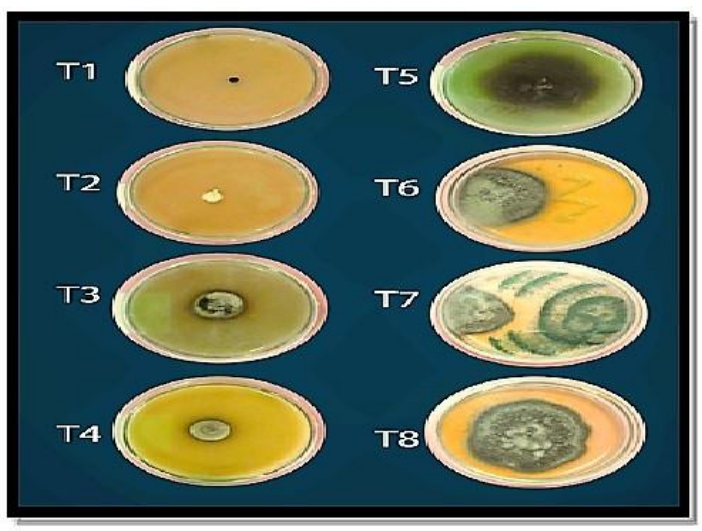

A. Food poison and Dual culture technique

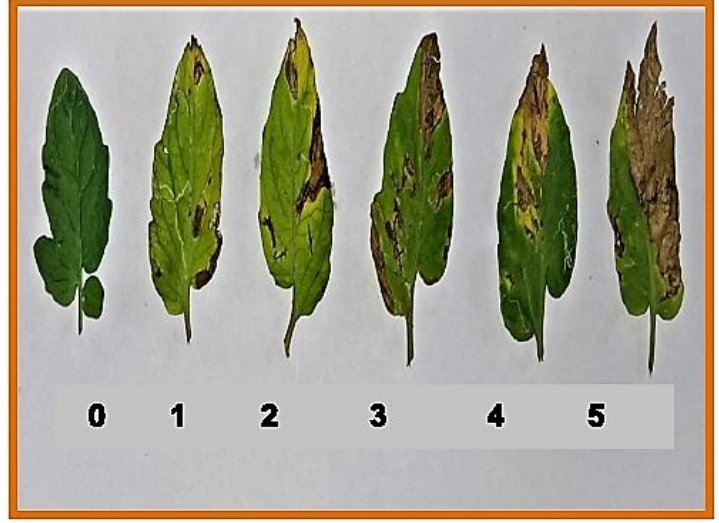

B. 0-5 description scale

$\begin{array}{cccc}\begin{array}{c}\text { Treatment } \\ \text { No. }\end{array} & \text { Treatment details } & \begin{array}{c}\text { Treatment } \\ \text { No. }\end{array} & \text { Treatment details } \\ \mathbf{T}_{1} & \text { Tebuconazole } & \mathbf{T}_{5} & \text { Copper oxychloride } \\ \mathbf{T}_{2} & \text { Propiconazole } & \mathbf{T}_{6} & \begin{array}{c}\text { Pseudomonas } \\ \text { fluorescens }\end{array} \\ \mathbf{T}_{3} & \begin{array}{c}\text { Carbendazim }+ \\ \text { Mancozeb }\end{array} & \mathbf{T}_{7} & \text { Trichoderma viride } \\ \mathbf{T}_{4} & \text { Mancozeb } & \mathbf{T}_{8} & \text { Control }\end{array}$
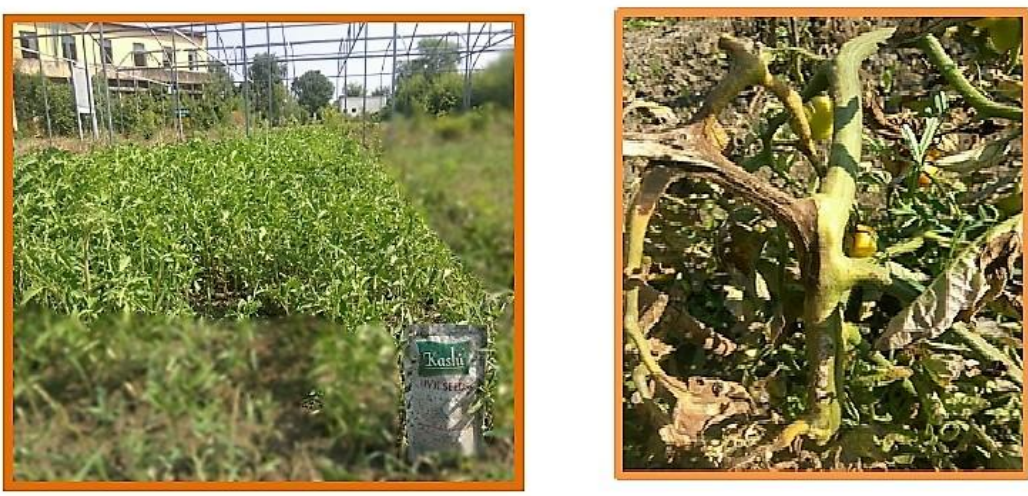

C. 30 days old nursery

D. Necrotic and concentric spots on stem

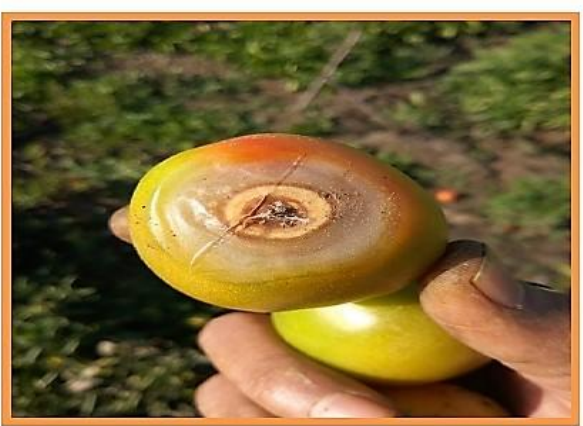

F. Necrotic and concentric spots on fruit

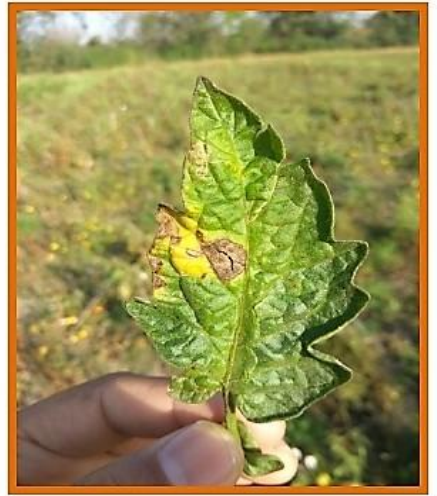

E. Necrotic and concentric spots on leaf 
The data on PDI of early blight was recorded by the using of 0-5 scale (Plate. B) 15 days after two consecutive sprays of fungicides at 15 days interval (Table 2). The data on disease intensity showed that all the tested fungicides reduce the disease intensity significantly as compared to untreated control. It is revealed from the data presented in (Table 2 and Fig. 2) that there was significant difference in per cent disease intensity during 2018-19. The minimum per cent disease intensity and maximum per cent disease control was observed in plottreated with Tebuconazole 25.9\% EC @ $0.1 \%$ (14.22\% and $73.50 \%)$ with maximum fruit yield (216.20q ha ${ }^{-1}$ ) followed by spraying of Propiconazole 25\%EC @ 0.1\% (17.55\% and $67.30 \%)$ with $\left(213.97 \mathrm{q} \mathrm{ha}{ }^{-1}\right)$, spraying of Mancozeb 75\% WP @ 0.25 \% (19.99 and $62.76 \%$ ) with $\left(178.20 \mathrm{q} \mathrm{ha} \mathrm{h}^{-1}\right)$, spraying of Carbendazim 12\% + Mancozeb $63 \%$ WP @ $0.15 \%$ (22.21\% and 58.62\%) with (164.63q ha $^{-1}$ ) and spraying of Copper Oxychloride 50 $\%$ WP @ 0.30\% (26.66\% and 50.33) with (162.17q ha $\left.{ }^{-1}\right)$, after two consecutive sprays at 15 days interval. In pooled data, all the treatments were significantly produced lower per cent disease intensity as compared to control. Among the bio control agents minimum PDI and maximum PDC was observed in plot treated with Trichoderma viride@0.25\% (19.55\% and 63.58\%) with fruit yield (179.93q ha ${ }^{-1}$ ), followed by Pseudomonas fluorescens @ 0.25\% (34.88\% and 35.02) with fruit yield (128.13q ha $\left.{ }^{-1}\right)$. Thus, application of Tebuconazole $25.9 \%$ EC ( $0.1 \%$ found better for management of early blight during the course of investigation in tomato followed by Propiconazole $25 \mathrm{EC}$ @ $0.1 \%$, Mancozeb 75\% WP @ $0.25 \%$, Carbendazim 12\% + Mancozeb 63\%WP@ $0.15 \%$ and Copper Oxychloride $50 \%$ WP @ $0.30 \%$ and among the bio control agents Trichoderma viride @ $0.25 \%$ was found better for management of early blight than Pseudomonas fluorescens @ 0.25\%. These results are in congruously with the results obtained by earlier research workers, Yadav et al., (2018) against Alternaria solani causing early blight of tomato. While Sharma et al., (2018) the lowest percent disease intensity (PDI) was observed in Carbendazim $12 \%$ + Mancozeb $63 \%$ WP @ $0.2 \%$ $(18.77 \%)$ with highest yield $(35257 \mathrm{~kg} / \mathrm{ha})$ followed by Difenoconazole 25 EC @ 0.025 $\%$ (20.59) and Propiconazole.

In conclusion, all the evaluated fungicides and bioagents are showed significant effect against Alternaria leaf blight of tomato under In vitro and In vivo. But Tebuconazole 25.9\% EC @ 0.1\%, Propiconazole 25\% EC @ 0.1\% and among tested bioagents Trichoderma viridae have shown highly suppression of Alternaria solani both in lab and field conditions.

\section{References}

Chandravanshi, S.S., Singh, B.P and Thakur, M.P. 1994. Persistence of different fungicides used against Alternaria alternata in tomato. Indian Phytopathol, 47: 241-244.

Datar, V. V and Mayee, C. D. 1981. Assesment of loss in tomato yield due to early blight. Indian Phytopathol. 34: 191-195.

Ellis, J.B and Martin, G.B. 1882. Macrosporium solani $\mathrm{E}$ and $\mathrm{M}$. American Naturalist16: 1003.

Gondal, A.S., Ijaz M., Riaz K and Khan, A.R. 2012. Effect of different doses of fungicide (Mancozeb) against Alternaria leaf blight of tomato in Tunnel. Plant Pathology and Microbiology. 3(3): 1-3.

Herle, G.S and Kamanna, B.C. 2014. In vitro and in vivo evaluation of fungicides against early blight of potato caused by Alternaria solani (ellis and martin) jones and grout. Plant Archives 
14(2):971-975.

Holm, A.L., Rivera, V.V., Secor, G.A and Gudmestad, N.C. 2003. Temporal sensitivity of Alternaria solani to foliar fungicides (Short communication). Amer J. of Potato Research. 80: 33-40.

Jones, L.R and Grout, A.J.1897. Notes on two species of Alternaria. Bulletin of the Torrey Botanical Society 24: 254-258.

Mallik I., Arabiat S., Pasche, J.S., Bolton, M.D., Patel, J.S and Gudmestad, N.C. 2014. Molecular characterization and detection of mutations associated with resistance to succinate dehydrogenase inhibiting fungicides in Alternaria solani. Phytopathology. 104:40-49

Morton and Srouble 1955. Antagonistic and stimulatory effects of microorganisms against upon Sclerotium rolfsci. Indian Phytopathology 45: 419-420.

Nene, Y.L and Thapliyal, P.N.1979. Fungicides in plant disease control. Oxford and JBH Publishing Company New Delhi. 413 p.

Pandey, K.K, Pandey, P.K and Sathpathy S. 2002. Integrated management of disease and insect of tomato, hot pepper and cole crop. Technical Bulletin No.9.IIVR Varanasi, pp.22.

Pasche, J.S., Piche, L.M and Gudmestad, N.C. 2005. Effect of the F129L mutation in Alternaria solani on fungicides affecting mitochondrial respiration. Plant Dis. 89:269-278.

Sahu, D.K., Khare, C.P., Singh, H.K and
Thakur, M.P., 2013. Evaluation of newer fungicide for management of early blight of tomato in Chhattisgarh. The Bioscan. 8(4): 1255-1259.

Shahbazi H., Aminian H., Sahebani N and Halterman D. 2011. Effect of Alternaria solani exudates on resistance and susceptible potato cultivars from two different pathogen isolates. The Plant Pathology Journal. 27(1): 14-19.

Sharma, R.K., Patel, D.R., Chaudhari, D.R., Kumar V and Patel, M.M. 2018. Effect of Some Fungicides against Early Blight of Tomato (Lycopersicon esculentum Mill.) Caused by Alternaria solani (Ell. and Mart.) Jones and Grout and their Impact on Yield. International Journal of Current Microbiology and Applied Sciences 7(07): 1395-1401.

Vijayalakshmi G., Karuna $\mathrm{K}$ and Mahadevaswamy G. 2018. Evaluation of Microbial Biocontrol Agents and Fungicides against Alternaria helianthi Causing Leaf Blight of Sunflower. International Journal of Current Microbiology and Applied Sciences 7(1): 2726-2730.

Yadav, V.K., Kumar V and Mani A. 2018. Evaluation of fungicides, biocontrol agents and plant extracts against early blight of potato caused by Alternaria solani. International Journal of Chemical Studies 6(1): 1227-1230.

\section{How to cite this article:}

Raavi Sreenivasulu, M. Surya Prakash Reddy, D.S. Tomar, M. Subhash Sri Sanjay and Bharath Bushan Reddy. 2019. Managing of Early Blight of Tomato Caused by Alternaria solani through Fungicides and Bioagents. Int.J.Curr.Microbiol.App.Sci. 8(06): 1442-1452. doi: https://doi.org/10.20546/ijcmas.2019.806.175 